\title{
Faktor-Faktor yang Berhubungan dengan Persepsi Pemuda Pada Pekerjaan Sektor Pertanian di Kabupaten Lampung Tengah
}

\section{Factors Related to Youth Perceptions of Agricultural Sector Work in Central Lampung Regency}

\author{
Oleh: \\ Andrius M. Pinem ${ }^{1 *}$, Indah Nurmayasari², Helvi Yanfika \\ ${ }^{1}$ Jurusan Agribisnis, Fakultas Pertanian, Universitas Lampung \\ ${ }^{2}$ Program Studi Magister Penyuluuhan dan Komunikasi Pertanian, Fakultas Pertanian, Universitas \\ Lampung.Jl. SumantriBrojonegoro 1, Bandar Lampung, 35145, Lampung, Indonesia \\ "E-mail: andrius.mpinem@gmail.com
}

Received February 08, 2020; Revised June 17, 2020; Accepted June 26, 2020

\begin{abstract}
ABSTRAK
Penelitian ini bertujuan untuk mengetahui faktor-faktor yang berhubungan dengan persepsi pemuda terhadap pekerjaan di sektor pertanian di Kabupaten Lampung Tengah. Penelitian ini dilakukan di Desa Simbar Waringin dan Desa Purwodadi Kecamatan Trimurjo serta Desa Sumber Fajar dan Desa Sumber Baru Kecamatan Seputih Banyak Kabupaten Lampung Tengah dengan menggunakan metode survei. Responden dalam penelitian ini adalah warga yang berjenis kelamin laki-laki dan perempuan. Sampel penelitian adalah 66 pemuda yang dipilih dengan menggunakan teknik pengambilan sampel proporsional random sampling. Untuk menganalisis faktor-faktor yang berhubungan dengan persepsi pemuda terhadap pekerjaan sektor pertanian menggunakan uji statistik non parametrik korelasi Rank Spearman. Hasil penelitian menunjukkan bahwa faktor-faktor yang berhubungan dengan persepsi pemuda terhadap pekerjaan di sektor pertanian adalah kebutuhan, pengaruh teman dan pengetahuan informasi, sedangkan faktor yang tidak berhubungan adalah tingkat pendidikan formal, lama berusahatani, tingkat motivasi, dan luas lahan.
\end{abstract}

Kata kunci: pemuda, pekerjaan, persepsi dan sektor pertanian

\begin{abstract}
The study aims to find out factors related to youth perceptions of agricultural sector work in Central Lampung Regency. This research was conducted in Simbar Waringin and Purwodadi Village in Trimurjo Subdistrict as well as Sumber Fajar and Sumber Baru Village in Seputih Banyak Subdistrict as many as Central Lampung Regency using survey methods. Respondetnt in this study were citizens who were male and female. The research sample was 66 youth selected using proportional random sampling. To analyze the factors related to youth perceptions of work in the agricultural sector using non parametric statistical test of rank spearman correlation. The results of study indicate that factors related to youth perceptions of work in the agricultural sector are needs, influence of friends, and information knowledge, while the factors that are not related are the level of formal education, length of farming, the level of motivation, and land area.
\end{abstract}

Keywords: youth, employment, perception, and agricultural sector 


\section{PENDAHULUAN}

Jumlah tenaga kerja di sektor pertanian di Indonesia mengalami penurunan dari tahun 2014 sampai tahun 2016 (BPS, 2017). Penurunan tenaga kerja ditunjukkan dari garis jumlah tenaga kerja di sektor pertanian yang semakin menurun dari tahun 2014 sampai tahun 2016. Data BPS menunjukkan bahwa pada tahun 2016 terjadi penurunan yang signifikan, yaitu sebesar 4,5\% dari tahun 2015. Penurunan jumlah tenaga kerja di sektor pertanian juga terjadi di salah satu Kabupaten di Indonesia, yaitu Kabupaten Lampung Tengah Provinsi Lampung.

Tenaga kerja di Kabupaten Lampung Tengah sebagian besar bekerja di sektor pertanian dengan jumlah 276.108 jiwa atau 15,57 persen, sektor manufaktur sebesar 131.035 jiwa (22,24 persen) dan sektor jasa sebesar 206.882 jiwa atau 16,25 persen (BPS Provinsi Lampung, 2018). Jumlah tenaga kerja buruh/karyawan/ pegawai lebih mendominasi di kalangan kaum muda dibandingkan dengan pekerja bebas (pekerjaan yang dilakukan oleh orang yang mempunyai keahlian khusus sebagai usahanya untuk memperoleh penghasilan) yaitu pada umur 20-24 tahun, sedangkan pekerja bebas mencakup pertanian dan non pertanian masih didominasi oleh orang dewasa hingga tua yang berumur 30 tahun ke atas.

Pergeseran tenaga kerja dari pertanian ke nonpertanian menjadi indikasi bahwa ada pergeseran preferensi kerja masyarakat pada bidang pertanian. Penurunan jumlah petani usia muda tersebut disebabkan oleh keinginan pemuda desa yang sudah memudar untuk bekerja di sektor pertanian, dan lebih cenderung memilih pekerjaan di sektor luar pertanian, baik di daerah desa tempat tinggalnya maupun di daerah perkotaan (Meilina, 2017).

Susilowati (2016) menyatakan bahwa bukan hanya dari segi ekonomi sektor pertanian semakin tidak menjanjikan, tetapi anak-anak muda tidak tertarik untuk bertani pada dasarnya dipengatuhi oleh budaya baru yang berkembang di era modern seperti saat ini. Kegagalan dalam pertanian lebih banyak dipublikasikan sehingga tidak sengaja menjadi mindset buruk bagi generasi muda. Persepsi yang buruk ini menjadi salah satu penyebab terjadinya penurunan tenaga kerja pada sektor pertanian sehingga sulit terciptanya pertanian yang berkelanjutan.

Pemuda yang memiliki minat tinggi untuk bekerja di bidang pertanian akan cenderung memiliki perasaan senang terhadap bidang pertanian (Lovea, 2015; Werembinan, Pakasai dan Pangemanan, 2018). Namun sebaliknya, apabila pekerjaan pada bidang pertanian tidak mampu menimbulkan rasa senang pada diri pemuda, maka pemuda tidak akan memiliki minat untuk bekerja di bidang pertanian. Oleh karena itu, tinggi rendahnya minat pemuda untuk bekerja di bidang pertanian, diyakini akan dipengaruhi oleh seberapa baik persepsi pemuda terhadap pekerjaan pada bidang pertanian (Lovea, 2015).

Persepsi merupakan situasi dimana setiap orang mengintepretasikan kondisi yang sama dengan cara yang berbeda dan setiap orang memiliki ekspektasi yang berbeda pula terhadap situasi yang sama (Hasanuddin et al., 2019). Oleh karena itu penafsiran secara subjektif terhadap lingkungan akan menentukan bagaimana seorang pemuda berperilaku. Persepsi pemuda terhadap kegiatan pertanian akan berdampak pada keberlanjutan sektor pertanian sehingga besar kemungkinan terjadinya pergeseran lapangan kerja. Penilaian atau kesimpulan terhadap objek yang diamati seorang pemuda dapat disebut dengan persepsi (Mearns, 2010). Penelitian ini bertujuan untuk mengetahui mengetahui faktor-faktor yang berhubungan dengan persepsi pemuda terhadap pekerjaan sektor pertanian di Kabupaten Lampung Tengah.

\section{METODE PENELITIAN}

Penelitian ini dilakukan pada empat Desa, yaitu Desa Simbar Waringin dan Desa Purwodadi Kecamatan Trimurjo serta Desa Sumber Fajar dan Desa Sumber Baru 
Kecamatan Seputih BanyakKabupaten Lampung Tengah. Lokasi ini ditentukan dengan cara sengaja (purposive) dengan pertimbangan bahwa pada empat desa tersebut merupakan desa yang memiliki hasil produktivitas sektor pertanian yang cukup tinggi di Kabupaten Lampung Tengah.

Responden dalam penelitian ini adalah warga yang berjenis kelamin laki-laki dan perempuan. Jumlah populasi pemuda pedesaan sebanyak 451 orang. Populasi pemudapedesaan yang terdapat di keempat desa diperoleh jumlah sampel sebanyak 66 responden pemuda. Teknik pengambilan sampel dilakukan dengan proporsional random sampling.

Analisis data yang digunakan adalah deskriptif kuantitatif untuk menganalisis faktor-faktor yang berhubungan dengan persepsi pemuda terhadap pekerjaan sektor pertanian. Pengujian hipotesis pada penelitian ini menggunakan statistik non parametrik korelasi Rank Spearman (Siegel, 1997) untuk melihat hubungan antara faktor-faktor yang berhubungan dengan persepsi pemuda pada pekerjaan di sektor pertanian dengan menggunakan rumus:

$$
r_{s}=1-\frac{6 \sum_{i=1}^{n} d i^{2}}{n^{3}-n}
$$

Keterangan:

rs = Koefisien korelasi

$\mathrm{di}=$ Perbedaan pasangan setiap peringkat

$\mathrm{n}=$ Jumlah sampel

\section{HASIL DAN PEMBAHASAN}

\section{Keadaan Umum Responden}

Jumlah responden pemuda pedesaan yang bekerja di pertanian terbanyak berada pada kelompok umur 26-30 tahun, sedangkan mayoritas pemuda dengan kelompok umur 21-25 tahun kurang berpartisipasi dalam berusahatani, hal ini disebabkan karena sebagian besar pemuda dengan kelompok umur 21-25 tahun sedang mencari dan memilih pekerjaan selain berusahatani. Rata-rata umur pemuda responden adalah 24 tahun dengan persentase sebesar 42,42 persen yaitu $(100 \%)$ berada pada usia produktif.

\section{Tingkat Pendidikan Formal (X1)}

Sebagian besar responden menempuh pendidikan terakhir SMA dengan jumlah persentase 90,91 persen. Tingkat pendidikan responden sudah termasuk tingkat pendidikan cukup tinggi disebabkan karena banyak masyarakat yang sudah menyadari pentingnya pendidikan formal.

\section{Lama Berusahatani (X2)}

Rata-rata lama berusahatani responden dalam penelitian ini berkisar antara 0 - 6 tahun yaitu 1,58 tahun. Sebagian besar responden termasuk dalam klasifikasi baru dalam berusahatani dengan persentase 72,73 persen berjumlah 48 orang. Minimnya pengalaman pemuda dalam berusahatani disebabkan oleh masih banyaknya responden yang tidak memiliki keahlian di bidang pekerjaan pertanian.

\section{Motivasi (X3)}

Responden dalam penelitian ini memiliki tingkat motivasi yang sedang dengan rata-rata skor yaitu 12,88 dengan persentase 25,76 persen, sedangkan 39,39 persen berada di klasifikasi tinggi dan sisanya berada di klasifikasi rendah. Hal ini menunjukkan bahwa motivasi pemuda yang tinggi karena responden terbanyak berada di pekerjaan campuran yang menganggap pertanian sebagai pekerjaan sampingan untuk mendapatkan pendapatan lebih dan saat ini merupakan era teknologi yang menyajikan berbagai informasi, salah satunya pertanian yang mempunyai prospek yang baik untuk masa depan. Teknologi dan informasi membuatnya mengenal pertanian tidak hanya pertanian konvensional saja melainkan pertanian organik dan pertanian modern lainnya. Selain itu, dengan 
banyaknya pemberitaan tokoh-tokoh sukses pertanian di media televisi maupun media sosial membuka wawasan dan penilaian pemuda akan pertanian yang lebih maju.

\section{Kebutuhan (X4)}

Responden dalam penelitian ini memiliki tingkat kebutuhan yang sedang berdasarkan teori pemenuhan kebutuhan maslow dengan rata-rata skor yaitu 9,74 dengan persentase 65,15 persen. Tingkat kebutuhan sedang tersebut dilihat dari lima indikator yaitu: Tingkat kebutuhan pemuda dari fisiologis (pangan, sandang dan papan), tingkat kebutuhan pemuda dalam memenuhi rasa aman, tingkat kebutuhan pemuda dalam memenuhi kebutuhan berinteraksi sosial, tingkat kebutuhan pemuda dalam memenuhi kebutuhan penghargaan, tingkat kebutuhan pemuda dalam memenuhi aktualisasi diri.

\section{Pengaruh Teman (X5)}

Responden dalam penelitian ini memiliki tingkat pengaruh teman yang tinggi, rata-rata skor yaitu 5,36 dengan persentase sebesar 89,39 persen. Hal ini berarti bahwa pengaruh dari teman yang tinggi terhadap pekerjaan di sektor pertanian. Artinya, bahwa interaksi pemuda dengan temannya untuk bercerita dan membahas masalah pertanian relatif tinggi. Pembahasan oleh teman pemuda biasanya mengenai harga-harga pertanian, bagaimana cara melakukan usahatani yang baik serta pasar dan peluang bisnis pertanian di masa depan.

\section{Pengetahuan Informasi (X6)}

Tingkat pengetahuan informasi sedang dengan rata-rata skor yaitu $7,14 \quad(65,15$ persen), sedangkan 34,85 persen pemuda berada pada klasifikasi rendah. Hal ini menunjukkan bahwa tingkat pemahaman pemuda terhadap hal-hal yang berkaitan dengan pekerjaan sektor pertanian sudah cukup tinggi.

\section{Luas Lahan (X7)}

Luas lahan responden dalam kegiatan berusahatani berkisar antara $0-1,00$ ha dengan rata-rata luas lahan yang sempit yaitu sebesar 0,27 ha. Sebagian besar pemuda $(68,18$ persen) memiliki luas lahan yang sempit, sedangkan 31,82 persen pemuda berada pada klasifikasi sedang dan tidak ada lahan pemuda berada pada klasifikasi luas. Lahan yang dimiliki pemuda saat ini semakin berkurang akibat adanya sistem waris dengan membagi rata tanah orang tua kepada anak-anaknya.

\section{Deskripsi Variabel Y (Persepsi Pemuda)}

Persepsi responden terhadap sektor pertanian dalam klasifikasi sedang sebesar 57,58 persen dan 42,42 persen pemuda berada pada klasifikasi rendah. Pekerjaan pertanian saat ini dapat dilakukan oleh siapapun baik yang berpendidikan tinggi dan rendah serta memiliki atau tidak memiliki kedudukan dalam desa. Bagi pemuda di Kabupaten Lampung Tengah, pekerjaan pertanian merupakan pekerjaan terhormat karena dapat menuai manfaat untuk makhluk hidup. Selain itu, pekerjaan pertanian tidak membuat gengsi atau harga diri pemuda turun dan direndahkan dalam masyarakat.

Persepsi negatif pada sektor pertanian disebabkan penilaian pemuda yang didominasi pada hal-hal yang kurang baik pada sektor seperti pemuda yang memiliki menganggap bahwa sektor pertanian lebih cocok bagi orang yang berpendidikan rendah dan tidak mempunyai jabatan di desa. Adanya ekspektasi dan harapan yang tinggi oleh pemuda untuk bekerja di luar pertanian juga turut menyumbang terhadap persepsi negatif terhadap pekerjaan di sektor pertanian.

Tiga indikator penilaian persepsi pemuda terhdap pertanian meliputi persepsi terhadap pendapatan, persepsi terhadap risiko, dan persepsi terhadap lingkungan kerja. Persepsi positif sektor pertanian terhadap pendapatan sebesar 72,73 persen 
(48 orang) dengan nilai sebesar 12,23. Hal ini menunjukkan bahwa persepsi pemuda terhadap pendapatan dari sektor pertanian tergolong baik dan prospektif untuk masa depan. Responden menilai pekerjaan di sektor pertanian dapat memenuhi kebutuhan dasar (pangan, sandang, dan papan).

Persepsi responden yang menilai negatif terhadap risiko pekerjaan disektor pertanian sebesar 6,52 dengan persentase 95,45 persen (63 orang). Hal ini menunjukkan bahwa hampir semua pemuda berpandangan buruk terhadap risiko pekerjaan pertanian karena rentan terhadap hama, resiko gagal panen dan ketergantungan terhadap cuaca. Meskipun lebih banyak pemuda laki-laki yang turun langsung ke sawah, tetapi tak membuat persepsi mereka tentang resiko usahatani menjadi positif. Para pemuda menilai belum ada solusi untuk menanggulangi resiko usaha dalam berusahatani. Resiko usaha dari pekerjaan di sektor pertanian tersebut telah membentuk persepsi yang negatif pada pemuda di Kabupaten Lampung Tengah.

Persepsi responden yang menilai negatif terhadap lingkungan kerja di sektor pertanian sebesar 7,12 dengan persentase 86,36 persen (57 orang). Hal ini menunjukkan bahwa penilaian pemuda terhadap lingkungan kerja pertanian tergolong negatif karena ketika bekerja di kebun mereka harus bekerja dengan berbagai kondisi cuaca, baik panas ataupun hujan. Bekerja sebagai petani berarti melakukan pekerjaan yang kotor dan berlumpur serta melelahkan, seperti pengolahan tanah, pemupukan, penanaman, sampai dengan pemanenan yang bertempat di ruang terbuka dan terkena matahari langsung. Di saat terik, pemuda harus tetap bekerja untuk menggarap lahan dan memastikan bahwa kebun mereka terawat.

Sebagian pemuda yang merasa bertani merupakan pekerjaan yang menyenangkan, tetapi mereka merasa bertani merupakan pekerjaan berat. Lain halnya jika bekerja sebagai buruh pabrik, menurut pemuda lebih nyaman karena tidak terpapar matahari secara langsung, aktivitas tidak terlalu berat dan terlindung dari hujan. Hal inilah yang membuat penilaian pemuda terhadap pekerjaan disektor negatif karena berusahatani lebih melelahkan daripada bekerja disektor lain.

\section{Analisis Hubungan Variabel X dan Y}

Hubungan antara variabel $\mathrm{X}$ (faktorfaktor yang mempengaruhi persepsi pemuda) dengan variabel $\mathrm{Y}$ (persepsi pemuda pada pekerjaan di sektor pertanian) dianalisis dengan menggunakan statistik non parametrik uji korelasi Rank Spearman dengan bantuan SPSS 24. Hasil pengujian statistik terhadap faktor-faktor yang diduga berhubungan dengan persepsi pemuda dapat dilihat pada Tabel 1 .

Dari Tabel 1, dapat dilihat bahwa faktor kebutuhan, pengaruh teman dan pengetahuan informasi berhubungan dengan persepsi pemuda terhadap pekerjaan di sektor pertanian Kabupaten Lampung Tengah, sedangkan tingkat pendidikan formal, lama berusahatani, motivasi dan luas lahan tidak berhubungan secara nyata.

Tabel 1.

Hasil analisis faktor-faktor yang diduga berhubungan dengan persepsi pemuda

\begin{tabular}{|c|c|c|c|c|}
\hline No & Variabel X & Variabel Y & $\begin{array}{r}\text { Koefisien } \\
\text { korelasi }\left(r_{s}\right)\end{array}$ & $\begin{array}{l}\text { sig. (2- } \\
\text { tailed) }\end{array}$ \\
\hline 1 & $\begin{array}{l}\text { Tingkat } \\
\text { pendidikan } \\
\text { Formal }\end{array}$ & & $-0,156^{\mathrm{tn}}$ & 0,212 \\
\hline 2 & $\begin{array}{l}\text { Lama } \\
\text { berusahatani }\end{array}$ & $\begin{array}{l}\text { Persepsi } \\
\text { pemuda pada }\end{array}$ & $-0,042^{\text {tn }}$ & 0,736 \\
\hline 3 & Motivasi & pekerjaan & $-0,062^{\text {tn }}$ & 0,619 \\
\hline 4 & Kebutuhan & sektor & $0,259 *$ & 0,035 \\
\hline 5 & Pengaruh teman & pertanian & $0,270 *$ & 0,028 \\
\hline 6 & $\begin{array}{l}\text { Pengetahuan } \\
\text { informasi }\end{array}$ & & $0,250 *$ & 0,043 \\
\hline 7 & Luas lahan & & $0,022^{\text {tn }}$ & 0,859 \\
\hline
\end{tabular}

Keterangan : Korelasi signifikan pada tingkat 0,05 (2-tailed) 


\section{Hubungan antara Tingkat Pendidikan Pemuda dengan Persepsi Pemuda terhadap Pekerjaan di Sektor Pertanian}

Nilai sig lebih besar daripada $\alpha$ yaitu $0,212>0,05$ pada taraf kepercayaan $95 \%$, sehingga dapat disimpulkan bahwa terima $\mathrm{H}_{0}$ maka tolak $\mathrm{H}_{1}$, berdasarkan hal tersebut, tidak adanya hubungan nyata antara tingkat pendidikan pemuda dengan persepsi pemuda terhadap pekerjaan di sektor pertanian terjadi karena sebagian besar pemuda di Kabupaten Lampung Tengah berpendidikan SMA, hal ini mempengaruhi cara berfikir pemuda tentang pekerjaan di sektor pertanian.

Pengujian hubungan antara tingkat pendidikan formal dengan persepsi pemuda pada pekerjaan sektor pertanian juga dilakukan menggunakan tabulasi silang, yang mana sebanyak 33 responden atau 50 persen memiliki klasifikasi tingkat pendidikan formal yang sedang dengan klasifikasi persepsinya terhadap pekerjaan sektor pertanian yang sedang. Sehingga tidak mengalami kenaikan persentase yang signifikan secara diagonal, hal ini membuat tingkat pendidikan tidak berhubungan nyata dengan persepsi terhadap pekerjaan sektor pertanian. Berdasarkan data tersebut, responden yang memiliki tingkat pendidikan formal sedang cenderung memiliki pola fikir atau persepsi yang tinggi terhadap pekerjaan sektor pertanian.

\section{Hubungan antara Lama Berusahatani dengan Persepsi Pemuda terhadap Pekerjaan}

Tidak terdapat hubungan nyata antara lama berusahatani dengan persepsi pemuda terhadap pekerjaan di sektor pertanian di Kabupaten Lampung Tengah. Berdasarkan hal tersebut, dapat disimpulkan bahwa pemuda yang telah lama bekerja ataupun baru bekerja memiliki persepsi yang sama terhadap pekerjaan di sektor pertanian. Responden menilai bertani dapat memberi kecukupan untuk memenuhi kebutuhan sehari-hari dan biaya pendidikan.

Pengujian hubungan antara lama berusahatani dengan persepsi pemuda pada pekerjaan sektor pertanian juga dilakukan menggunakan tabulasi silang, bahwa sebanyak 29 responden (43,9 persen) memiliki pengalaman berusahatani yang rendah dengan klasifikasi persepsi terhadap pekerjaan sektor pertanian sedang. Responden yang memiliki pengalaman berusahatani rendah disebabkan karena banyak pemuda yang tidak memiliki keahlian di bidang pertanian (bekerja diluar sektor pertanian) dan terbatasnya lahan pertanian untuk diolah.

Hubungan antara Motivasi dengan Persepsi Pemuda terhadap Pekerjaan di Sektor Pertanian

Nilai sig lebih besar daripada $\alpha$ yaitu $0,619>0,05$ pada taraf kepercayaan 95\%, sehingga dapat disimpulkan bahwa terima $\mathrm{H}_{0}$ maka tolak $\mathrm{H}_{1}$, yaitu tidak ada hubungan nyata antara motivasi dengan persepsi pemuda terhadap pekerjaan di sektor pertanian. Hal tersebut karena sebanyak 32 responden hanya bekerja di luar sektor pertanian dan sebagian pemuda masih menganggap pertanian sebagai pekerjaan sampingan atau tambahan saja. Secara umum responden sudah menggunakan smartphone yang membuat mereka mudah dalam mencari berbagai informasi termasuk pertanian sehingga memudahkan pemuda untuk mendapatkan pendapatan lebih. Teknologi dan informasi membuat pemuda mengenal tidak hanya pertanian konvensional saja melainkan pertanian organik dan pertanian modern dan lainnya (Wahyuni, 2019; Listiana et al., 2019; Adriyani, 2019). . Selain itu, banyaknya pemberitaan tokoh-tokoh yang sukses dalam bidang pertanian di televisi maupun media sosial (facebook) menyebabkan pemuda memiliki wawasan terhadap pertanian yang lebih maju. 
Hubungan antara Kebutuhan dengan Persepsi Pemuda terhadap Pekerjaan di Sektor Pertanian

Nilai sig lebih kecil daripada $\alpha$ yaitu $0,035<0,05$ pada taraf kepercayaan $95 \%$, sehingga dapat disimpulkan bahwa terima $\mathrm{H}_{1}$ maka tolak $\mathrm{H}_{0}$, yaitu terdapat hubungan nyata antara kebutuhan dengan persepsi pemuda terhadap pekerjaan di sektor pertanian di Kabupaten Lampung Tengah. Hal tersebut karena cukup tingginya tingkat keinginan pemuda di Kabupaten Lampung Tengah dalam memenuhi kebutuhan fisiologis (sandang, pangan dan papan), kebutuhan rasa aman, kebutuhan sosial, kebutuhan penghargaan dan kebutuhan aktualisasi diri.

Hubungan antara Pengaruh Teman dengan Persepsi Pemuda terhadap Pekerjaan di Sektor Pertanian

Nilai sig lebih kecil daripada $\alpha$ yaitu $0,028<0,05$ pada taraf kepercayaan $95 \%$, sehingga dapat disimpulkan bahwa terima $\mathrm{H}_{1}$ maka tolak $\mathrm{H}_{0}$, yaitu terdapat hubungan nyata antara pengaruh teman dengan persepsi pemuda terhadap pekerjaan di sektor pertanian. Semakin tinggi interaksi pemuda dengan teman untuk membahas masalah dan peluang dalam bisnis pertanian, maka akan semakin positif persepsi pemuda terhadap pekerjaan pertanian. Kedekatan dengan teman yang bekerja sebagai petani akan mempengaruhi penilaian pemuda terhadap pertanian yang meliputi pendapatan, risiko dan lingkungan kerja dari petani.

\section{Hubungan antara Pengetahuan Informasi dengan Persepsi Pemuda terhadap Pekerjaan di Sektor Pertanian}

Terdapat hubungan nyata antara pengetahuan informasi dengan persepsi pemuda terhadap pekerjaan di sektor pertanian. Cukup tingginya tingkat pengetahuan pemuda dikarenakan saat ini merupakan era teknologi dan banyaknya pemuda yang sudah menggunakan smartphone sehingga bisa mencari berbagai informasi termasuk pertanian yang mempunyai prospek yang baik untuk masa depan, teknologi dan informasi membuatnya mengenal pertanian tidak hanya pertanian konvensional saja melainkan pertanian organik, pertanian modern, dan lainnya.

Hubungan antara Luas Lahan dengan Persepsi Pemuda terhadap Pekerjaan di Sektor Pertanian

Nilai Sig lebih besar daripada $\alpha$ yaitu $0,859>0,05$ pada taraf kepercayaan $95 \%$, sehingga dapat disimpulkan bahwa terima $\mathrm{H}_{0}$ maka tolak $\mathrm{H}_{1}$, yaitu tidak ada hubungan nyata antara luas lahan dengan persepsi pemuda terhadap pekerjaan di sektor pertanian. Pemuda menilai pekerjaan di sektor pertanian bukan berdasarkan lahan yang dimilikinya melainkan penggunaan teknologi yang dapat menarik minat pemuda terhadap sektor pertanian modern dimasa yang akan datang dengan potensi pendapatan yang tinggi. Sebanyak 23 responden atau 34,8 persen memiliki klasifikasi luas lahan yang sempit dengan klasifikasi persepsinya terhadap pekerjaan sektor pertanian yang sedang. Semakin sempitnya lahan yang dimiliki responden disebabkan adanya sistem waris dengan membagi rata tanah kepada anak-anaknya dan semakin bertambahnya jumlah penduduk secara keseluruhan.

\section{SIMPULAN}

Pemuda desa saat ini telah banyak meninggalkan pekerjaan pertanian, terlihat dengan usaha mereka untuk melamar pekerjaan dan mengalami beberapa kali pergantian pekerjaan di luar sektor pertanian. Pemuda desa saat ini tidak tahu lagi bagaimana caranya bertani, hal ini terkait dengan sudah sangat jarang orangtua yang masih mengajarkan pertanian kepada anaknya. Pemuda desa di Kabupaten Lampung Tengah masih mau bekerja di 
sektor pertanian hanya sebagai pekerjaan sampingan mereka, tidak menjadi pekerjaan utama karena pertanian dapat membantu menambah penghasilan. Faktor-faktor yang berhubungan dengan persepsi pemuda terhadap pekerjaan di sektor pertanian adalah kebutuhan, pengaruh teman dan pengetahuan informasi, sedangkan faktor yang tidak berhubungan adalah tingkat pendidikan formal, lama berusahatani, motivasi dan luas lahan.

\section{DAFTAR PUSTAKA}

Adriyani, F.A. (2019). Pemanfaatan Cyber Extension Sebagai Media Diseminasi Inovasi Pertanian oleh Penyuluh Pertanian di Provinsi Lampung. Suluh Pembangunan : Journal of Extension and Development. 1(1):: 1-7.

BPS [Badan Pusat Statistik] Provinsi Lampung. 2017. Jumlah Tenaga Kerja di SektorPertanian di Indonesia pada Tahun 2014-2016. Badan Pusat Statistik Provinsi Lampung. Bandar Lampung. Diakses pada tanggal 01 Februari 2019.

BPS [Badan Pusat Statistik] Provinsi Lampung. 2018. Lampung dalam Angka 2018. Bandar Lampung. Diakses pada tanggal 01 Februari 2019.

Hasanuddin, T., Viantimala, B., dan Fitriyani, A. (2019). Kinerja Penyuluh Pertanian Lapangan, Kepuasan Petani, dan Produktivitas Usahatani Jagung di Kecamatan Natar, Kabupaten Lampung Selatan. Suluh Pembangunan : Journal of Extension and Development. 1(2): 134-141.

Listiana, I., Efendi, I., Mutolib, A., \& Rahmat, A. (2019). The behavior of Extension Agents in Utilizing Information and Technology to Improve the Performance of Extension Agents in Lampung Province. Journal of Physics:
Conference Series, 1155(1 (012004)), 1-10. https://doi.org/10.1088/17426596/1155/1/012004

Lovea, R. 2015. Pengaruh Persepsi Terhadap Minat Pemuda Bekerja Pada Bidang Pertanian Di Kabupaten Jepara. http://etd.repository.ugm.ac.id /index.php?mod=penelitian_detail\&s $\mathrm{ub}=$ PenelitianDetail\&act=view\&typ $=\mathrm{html} \&$ buku id $=87234 \&$ obyek_id=4. Diakses Pada tanggal 01 Februari 2019.

Mearns, J. 2010. The Social Learning Theory of Julian B. Rotter.http://psych.fullerton.edu/ jmearns/rotter.html. Diakses pada tanggal 26 Februari 2019.

Meilina, H. dan R. Virianita. 2017. Persepsi Remaja Terhadap Pekerjaan Di Sektor Pertanian Padi Sawah Di Desa Cileungsi Kecamatan Ciawi Kabupaten Bogor.JSKPM, Vol. 1. No.3. http://www.readcube.com/ articles/10.29244/jskpm.1.3.339-358. Diakses Pada tanggal 02 Februari 2019.

Siegel, S. 1997. Statistik Non-Parametrik Ilmu-ilmu Sosial. PT Gramedia. Pustaka Utama. Jakarta.

Susilowati, S.H. 2016. Fenomena Penuaan Petani dan Berkurangnya Tenaga Kerja Muda serta Implikasinya bagi Kebijakan Pembangunan Pertanian. Forum Penelitian Agro Ekonomi, 34 (1): 35-55.

Wahyuni, S. (2019). Hubungan Karakteristik Inovasi dan Pola Komunikasi Terhadap Keberlanjutan Penerapan Teknologi Padi Salibu di Kabupaten Tanah Datar. Suluh Pembangunan : Journal of Extension and Development. 1 (2): 72-80.

Werembinan, C.S., Pakasi, C.B.D., dan Pangemanan, L.R.J. 2018. Persepsi Generasi Muda Terhadap Kegiatan Pertanian di Kelurahan Buha Kecamatan Mapanget Kota Manado. Agri-Sosio Ekonomi Unsrat, 14(3):123 - 130 